\title{
Bacterial Production of Protease-A Preliminary Study
}

\author{
R. Anusuya ${ }^{1}$, K. Srimathi ${ }^{2}$ \\ ${ }^{1,2}$ Annamalai University, Parangipettai, Tamil Nadu
}

Available online at: www.isroset.org

Received: 27/Oct/2018, Accepted: 05/Dec/2018, Online: 31/Dec/2018

\begin{abstract}
Proteolytic enzyme, also called protease, proteinase, or peptidase, any of a group of enzymes that break the long chainlike molecules of protein into shorter fragments (peptides) and eventually into their components, amino acids proteolytic enzymes are present in bacteria. Protease are produced from various sources but only little information is available regarding the bacterial population in fish wastes of Chidambaram fish market and their efficiency in synthesizing protease enzyme. Isolated 25 bacterial strains and found that only 5 of them are capable of producing protease enzyme that are Pseudomonas $s p$. and Bacillus sp. was the best protease producer among the tested strains. In the present study, all the bacterial species isolated had a better potentiality of degrading market fish wastes.
\end{abstract}

Keywords- Protease, Enzyme, Pseudomonas and Bacillus

\section{INTRODUCTION}

Enzymes are proteins which require a specific substrate on which to work (Okononko et al., 2006). Microorganisms in particular have been regarded as treasure sources of useful enzymes (Shimizu et al., 1997). Biologically active enzymes may be extracted from living organisms. Extracellular enzymes are preferred, because difficult and costly methods of cell disruption are not necessary for their extraction. Microbial enzymes present a wide spectrum of characteristics that make them utilizable for quite specific applications (Hossain et al., 2005). Of the several enzymes being used industrially, over a half is from fungi and yeast and over a third are from bacteria (Ashok Pandey et al., 2000: Meenu et al., 2000).

The demand for industrial enzymes, particularly of microbial origin is ever increasing owing to their applications in a wide variety of processes. Enzyme mediated reactions are attractive alternatives to tedious and expensive chemical methods. Enzyme find great use in a large number of fields such as food, dairy, pharmaceutical, detergent, textile and cosmetic industries ( Saxena et al., 1993). Current developments in biotechnology are yielding new applications for enzymes (Pandey et al., 2000).

Protease is enzymes which cleave or cut or degrade other proteins by hydrolysing peptide bonds. Proteases are one of the most important groups of industrial enzymes and account for nearly $60 \%$ of the total enzyme sale (Dutta and Banerjee, 2006). Most of the available proteases produced commercially are of microbial origin (Oskouie et al., 2007).

Manivannan et al. (2004) studied the production of alkaline protease by Aspergillus sp. Shik et al. (2006) studied the production of alkaline protease by Bacillus pantothenticus. Soares et al. (2005) isolated extracellular protease from Bacillus subtilis. Investigation on extracellular protease production by Bacillus cereus which was isolated from the intestine of fish, Mugil cephalus was carried out by Esakkiraj et al. (2008).

\section{MATERIALS AND METHODS}

\section{Collection of sample}

Fish wastes were collected from a fish market at Chidambaram, Cuddalore District and were aseptically transferred to the laboratory for further study.

\section{Isolation of bacterial flora}

In the laboratory, the samples serially diluted upto $10^{-5}$ dilution. From each dilution, $0.1 \mathrm{ml}$ of sample was taken and spread plated on Zobell agar medium. The plates were then incubated at 370C for 24 to $48 \mathrm{~h}$. The total viable counts (TVC) of the 
colonies were finally noted. The isolated cultures were purified individually by streaking on nutrient agar plates and were sub cultured.

\section{Identification of bacteria}

The bacterial cultures were identified up the genus level by performing the following biochemical tests:

\section{Gram's staining}

The different bacterial cultures (16 to $18 \mathrm{hrs}$.) were smeared on clean glass slides individually and heat fixed. The smears were flooded with crystal violet for a min. and the stain was washed off using distilled water. The smears were flooded with Gram's stain iodine solution (fixative) for a min. and rinsed with distilled water, decolourized with acetone alcohol, rinsed out and the smears were counter stained with saffranin, air dried and examined under oil immersion microscope. Gram positive bacteria were purple or violet and Gram negative bacteria were in red colour when observed.

\section{Motility test}

A depression slide and the cover glass were located well. A small drop of bacterial culture was spreaded around the edges of the cover glass and inverted carefully by lowering it towards the depression slide until it made contact with Vaseline, which was spread around the concavity. The slide was turned upright and drop of culture remained suspended from the cover glass, which was then observed under oil immersion microscope. Thus the motility of bacteria was noted.

\section{Indole production test}

Trytone broth tubes were prepared and sterilized at $1210 \mathrm{C}$ for $15 \mathrm{~min}$. The cultures were then inoculated and incubated individually at $37 \mathrm{o} \mathrm{C}$ for $24-48$ hours. After the incubation period, a few groups of $(0.2 \mathrm{ml})$ Kovac's reagent was added into the tubes and the result was observed. The development of bright red colour at the interface of reagent and medium indicated the presence of indole and constituted a positive test. The absence of colour at this interface the negative test.

\section{Methyl red test}

The MR-VP broth tubes were prepared and sterilized at $1210 \mathrm{C}$ for minutes. The cultures were then inoculated individually into the tubes containing sterilized period, about 5 to 6 drops of methyl red indicator solution was added. The development of stable bright red colour indicated sufficient acid production and constituted a positive reaction. A weekly positive test indicated red orange colour. A yellow orange colour indicated a negative reaction.

\section{Voges-Proskauer test}

The MR-VP broth tubes were prepared and sterilized at $121^{\circ} \mathrm{C}$ for $15 \mathrm{~min}$. The cultures were then inoculated into the tubes containing sterilized MR-VP broth medium and incubated in the tubes at $37 \mathrm{o} \mathrm{C}$ for $24-48$ hours. After the incubation period, about $3 \mathrm{ml}$ of $5 \%$, -napthol in absolute ethanol and $1 \mathrm{ml}$ of $40 \%$ potassium hydroxide (plus creatine) were added. The tubes were allowed to remain undisturbed for 15-20 min. The development of red colour indicated the production of oxidation product acetoin from diacetyl and constituted the positive test. The absence of the red colour indicated negative reaction.

\section{Citrate utilization test}

Simmons citrate agar was prepared and dispensed on test tubes and sterilized at $1210 \mathrm{C}$ for $15 \mathrm{~min}$ and allowed to set as slope. The cultures were then inoculated individually into the tubes containing Simmons citrate agar slants (Stabbed into the bud and streaked on the surface of slants) and incubated at $370 \mathrm{C}$ for $24-48$ hours. After the incubation period, the development of intense blue colour from the original green colour of the medium indicated the ability of the organism to utilize citrate as carbon source and constituted the positive reaction. The absence of blue colour indicated negative reaction.

\section{Oxidase test}

Strips of Whatsmann No. 1 filter paper was soaked in a freshly prepared 1\% solution of tetramethyl paraphenyl diamine dihydrochloride and dried. The isolates were streaked individually on the prepared filter paper with a sterile platinum loop. A positive reaction was indicated by an intense deep purple colour appearing within 5-10 seconds and a negative reaction by absence of colouration.

\section{Urease test}


Urease is a hydrolytic enzyme that attacks the nitrogen and carbon bounds amide compounds like urea and formalin alkaline end product such as ammonia. The bacterial cultures were inoculated individually in Christensen's agar slant and incubated at $370 \mathrm{C}$ and the reactions were recorded after 4, 8, 12 and $48 \mathrm{~h}$ of incubation. The production of enzyme urease was detected by a change in the colour of the medium from yellow to purple.

\section{Triple sugar iron test (TSI)}

TSI test is used to differentiate different group of Enterobateriaceae from other gram negative Bacilli. The bacterial isolate were inoculated individually in the TSI agar slant by stabbing the butt down to the bottom and then the surface of the slant was streaked incubated at $37^{\circ} \mathrm{C}$ for $18-24$ hours. The following three types of results after inoculation were detected.

a. Acid butt, alkaline slant (yellow butt, red slant) - glucose has fermented but not lactose nor sucrose.

b. Acid butt, acid slant (yellow butt, yellow slant) - lacose and/ or sucrose has fermented.

c. Alkaline butt, alkaline slant (Red butt, red slant) - either glucose, lactose or sucrose has fermented.

Gas production: Indicated by bubbles in the butt or the agar may be broken or pushed upwards.

Hydrogen sulphide production: Indicated by blackening of the butt.

\section{Fermentation of carbohydrate}

The bacterial species isolated were checked for their ability to ferment various carbohydrates (lactose, mannitol, sucrose, dextrose).

Oxidation - fermentatioin basal medium was prepared with $1 \%$ of different sugars each and sterilized and inoculated with 2 or 3 loopful of $18-24 \mathrm{hrs}$ old broth culture into sterile fermentation medium and incubated for $24-48 \mathrm{~h}$ at $30{ }^{\circ} \mathrm{C}$ in an incubator.

A change in the colour of the medium to yellow indicated acid reaction.

\section{Starch hydrolysis test}

Starch agar plates containing a loopful of cultures was incubated for 24 hours at $37^{\circ} \mathrm{C}$. After incubation, the plates were flooded with iodine solution, clear zone around the growth indicated positive hydrolysis. No change of starch resulted in blue colour and indicated negative hydrolysis.

\section{Casein hydrolysis test}

Skim - milk agar plates were prepared and streaked with the bacterial isolates. The plates were then incubated at $37^{\circ} \mathrm{C}$ for $24-28 \mathrm{hrs}$. The positive organisms formed zones while the casein negative organisms does not form zones.

\section{Gelatin hydrolysis test}

The organisms were inoculated individually in the gelatin agar and incubated for 48 hours at $37^{\circ} \mathrm{C}$. After incubation, mercuric chloride solution was added and allowed to stand for 5-10 minutes. Formation of clear zone around the colony indicated positive result.

\section{Catalase test}

A nutrient agar slant was inoculated with the test culture and was incubated at $37^{\circ} \mathrm{C}$ for 24 hours. Then, $1 \mathrm{ml}$ of $3 \%$ hydrogen peroxide was trickled down the slant and was examined immediately and after 5 minutes for the evolution of bubbles, which indicated a positive test,

\section{Nitrate reduction test}

Nitrate broth was prepared and $5 \mathrm{ml}$ was dispensed in test tubes. The isolates were inoculated individually into nitrate broth. The tubes were then incubated at $37^{\circ}$ for $96 \mathrm{~h}$. After incubation, $0.1 \mathrm{ml}$ of sulphinilic acid and alpha naphthalamine were added and mixed well. Nitrate positive organisms showed a red colour while the negative organisms did not show any red colouration.

\section{Screening for protease production}


Skim milk agar (Components (g/l): Skim milk powder: 100 g: Peptone: 5.0 g: Agar: 15.0 g: pH: 7.2) plates were prepared and streaked with test organisms. They were then incubated at $37^{\circ} \mathrm{C}$ for $24-48 \mathrm{~h}$. After incubation, the plates were flooded with $\mathrm{HgCl}_{2}$ solution and were observed for zone formation (Plates 1, 2, \& 3).

III. RESULTS

\section{Isolation of bacteria}

The total viable count of bacterial colonies recorded in fish waste sample was $181 \times 102 \pm 0.23 \mathrm{CFU} / \mathrm{g}$ in $10-1$ dilution and $50 \times 106 \pm 0.13 \mathrm{CFU} / \mathrm{g}$ in 10-5 dilution (Table.1).

Table.1 Total viable counts of bacterial colonies at different dilutions.

\section{Identification of bacteria}

\begin{tabular}{|c|c|c|}
\hline Sl.No & Dilution & Number of colonies (CFU/g) \\
\hline 1. & $10^{-1}$ & $181 \times 10^{2}$ \\
\hline 2. & $10^{-2}$ & $145 \times 10^{3}$ \\
\hline 3. & $10^{-3}$ & $102 \times 10^{4}$ \\
\hline 4. & $10^{-4}$ & $83 \times 10^{5}$ \\
\hline 5. & $10^{-5}$ & $50 \times 10^{6}$ \\
\hline
\end{tabular}

Based on the morphological, physiological and biochemical and characteristics, Bacillus sp. and Pseudomonas sp. of bacteria were identified (Table.2).

Table 2. Morphological, physiological, Carbohydrate fermentation and biochemical characteristics of identified bacterial strains.

\begin{tabular}{|c|c|c|c|c|c|c|c|c|c|c|c|c|c|c|c|c|}
\hline$\underset{\dot{n}}{\stackrel{0}{Z}}$ & $\stackrel{\Xi}{\underline{\Xi}}$ & 预 & 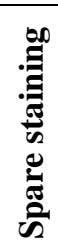 & $\mathscr{N}^{\prime}$ & 竞 & 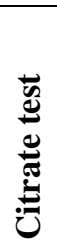 & 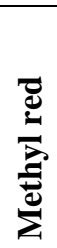 & $\frac{\vec{y}}{\stackrel{\Delta}{\Delta}}$ & 苋 & Uू. & $\frac{0}{\frac{0}{0}}$ & 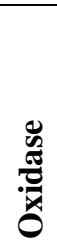 & 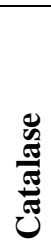 & 䓻 & $\ddot{\mathscr{D}}$ & Identified organisms \\
\hline 1. & S. 1 & $\mathrm{G}(+)$ rods & + & - & - & - & - & + & - & - & - & - & + & + & $\mathrm{K} / \mathrm{A}$ & Bacillus sp. \\
\hline 2. & S.2 & $\mathrm{G}(+)$ rods & + & - & + & - & + & - & - & + & + & - & + & + & $\mathrm{K} / \mathrm{A}$ & Bacillus sp. \\
\hline 3. & S.3 & $\mathrm{G}(+)$ rods & + & - & - & - & + & + & - & + & - & - & + & + & $\mathrm{K} / \mathrm{K}$ & Bacillus sp. \\
\hline 4. & S.4 & $\mathrm{G}(-)$ rods & - & - & + & + & - & - & - & - & + & + & + & - & $\mathrm{K} / \mathrm{A}$ & Pseusomonas sp. \\
\hline 5. & S.5 & $\mathrm{G}(-)$ rods & - & - & - & + & - & - & - & - & + & + & + & - & $\mathrm{K} / \mathrm{A}$ & Pseudomonas sp. \\
\hline
\end{tabular}

+= Positive; - = negative ; K/A= Alkaline slant/ acid butt; and K/K Alkaline slant/ alkaline butt

All the Bacillus sp. of bacteria of the present study are Gram positive whereas, all the Pseudomonas sp. is Gram negative (Table 2).

\section{Screening for protease production}

All the identified bacterial species showed positive proteolytic activities (Table.3).

Table 3. Different enzymatic activities of identified bacterial strains.

\begin{tabular}{|c|c|c|}
\hline Culture. No & Bacterial strains & Proteolytic activity \\
\hline S1 & Bacillus $s p$. & + \\
\hline S2 & Bacillus $s p$. & + \\
\hline S3 & Bacillus $s p$. & + \\
\hline S4 & Pseudomonas $s p$. & + \\
\hline S5 & Pseudomonas $s p$. & + \\
\hline
\end{tabular}

$+=$ positive enzyme activity 
Fig1. Protease activity of isolated bacteria in skim milk agar medium

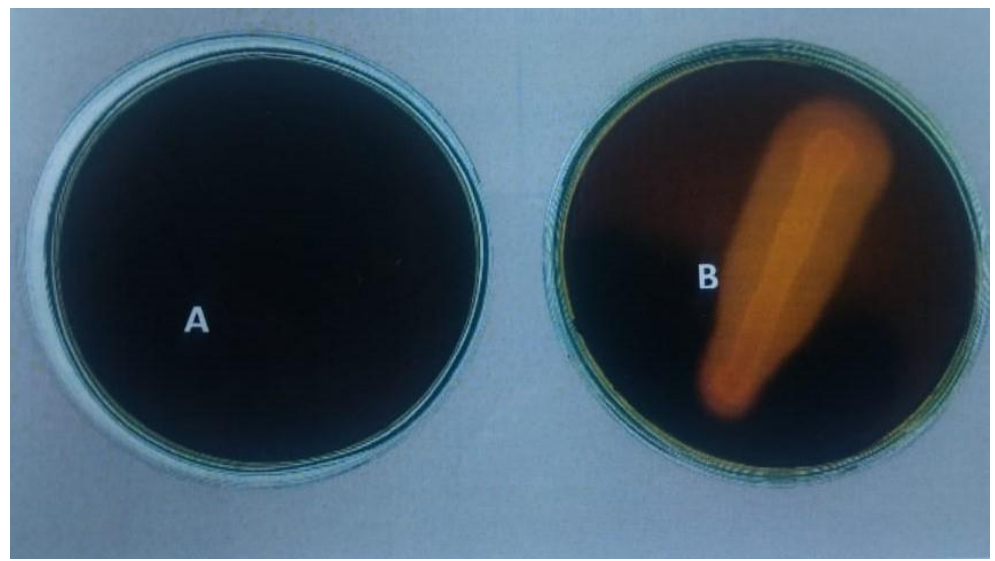

A: Control

B: Bacillus sp.

Fig 2. Protease activity of isolated bacteria in Skim milk agar medium

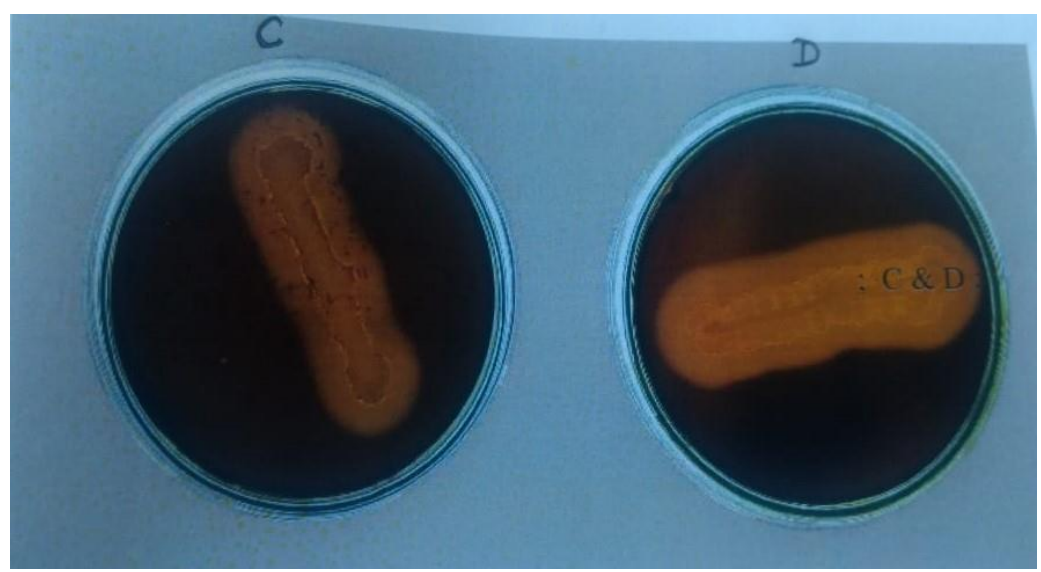

C and D: Bacillus. Sp

Fig 3. Protease activity of isolated bacteria Skim milk agar medium

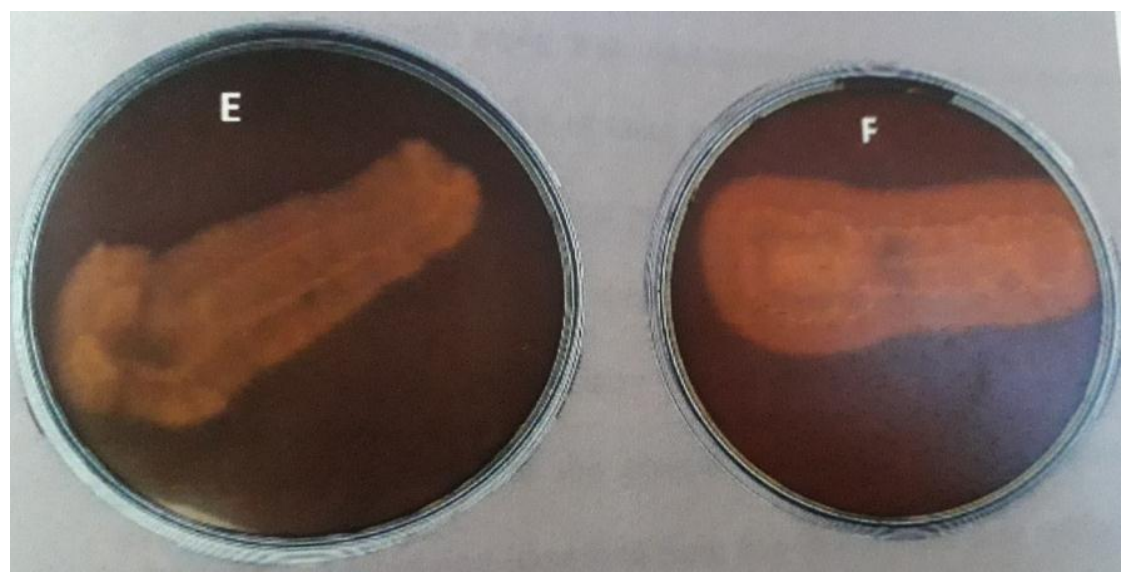

E \& F: Pseudomonas sp.

IV. DISCUSSION 
Fish waste is one of the common spillage in every fish market area. (ukami et al. 2002). Proteolytic bacterial of fish wastes and their enzyme production abilities are very interesting and hence the present study was undertaken. (Cheong et al., 2014). The isolated 25 bacterial strains and found that only 19 of them are capable of producing protease enzyme and revealed that, those strains with highest protease activity will have a better potential of degrading the proteins presenting shrimp shell wastes. In the present study, all the five isolated bacteria produced protease. Moriarty (1999) stated that, Bacillus $s p$. are generally present in the marine sediments. Similarly, Hoshino et al. (1997) isolated a Pseudomonas sp. from fish which was capable of producing protease enzyme. Sabir et al. (2009) reported that, B.subtilis was the best protease producer among the tested strains. In the present study also, different Bacillus sp. and Pseudomonas sp. were isolated and identified from fish wastes and their ability to produce pretease enzyme was qualitatively studied. Similarly, Hoshino et al. (1997) isolated a Pseudomonas sp. from fish which was capable of producing protease enzyme. Sabir et al. (2009) reported that, B.subtilis was the best protease producer among the tested strains. In the present study, all the bacterial species isolated had a better potentiality of degrading market fish wastes.

\section{ACKNOWLEDGEMENT}

I am extremely grateful to my beloved guide Dr. H. ANN SUJI, Assistant Professor, Centre of Advanced Study in Marine Biology, Faculty of Marine sciences, Annamalai University for suggesting the problem, designing the plan of work, constant encouragement, valuable comments and discussion in every phase of my research work. I have on wards to express my thankfulness for his helping sense of cordial affection towards me.

\section{REFERENCES}

[1]. Abidi,F., F.Limam, M. Marzouki and Neji, 2008, Production of alkaline protease by Botrytis cinerea using economic raw materials : Assay as biodetergent. Process.Biochem. 43:1202-1208.

[2]. Adinarayana, K and P. Ellaiah, 2002. Response surface optimization of critical medium components for the production of alkaline protease by a newly isolated Bacillus sp. J.Pharm.Sci., J5:272-276.

[3]. Adinarayana, K., P. Ellaiah, and D.S. Prasad, 2003. Purification and partial characterization of thermostable serine alkaline protease from a newly isolated Bacillus subtilis PE-11, AAPS Pharm. Sci. Tech., 4:56pp.

[4]. Afify, A.E.M.R., M.A.M. Aboul-soud, M.S.Foda,M.W.A.Sadik, T. Kahil,A.R.Asar and A.A.A1-Khedhairy,2009. Production of alkaline protease and larvicidal biopesticides by an Egyptian Bacillus sphaericus isolate. African J.Biotechnol., 8:3864 - 3873.

[5]. Annamalai, N.,M.V. Rajeswari and T.Balasubramanian, 2013. Extraction, purification and applicaton of thermostable and halostable alkaline protease from Bacillus alveayuensis CAS 5 using marine waste. Food and products processing. Doi.org/10.1016/j.fbp.2013.08.009.

[6]. Annamalai, N., M.V. Rajeswari, Sunil Kumar Sahu and T.Balasubramanian, 2014. Purification and characterisation of solvent stable, alkaline proteasefrom Bacillus firmus CAs 7 by microbial conversion of marine wastes and molecular mechanism underlying solvent stability. Process Biochem.,_http;//dx.doi.org/10.1016/j.2013.08.009.

[7]. Arulmani, M., K.Aparanjini, K. Vasanthi, P. Arumugam, M.Arivuchelvi and T. Kalaichelvan, 2006. Purification and partial charecterisation of serine protease from thermostable alkalophilic Bacillus laterosporus-AK1. World J.Microbiol.Biotechnol., 23; 475-481.

[8]. Ashok Pandey, Carlos R. Soccol and Vanete T. Soccol, 2000. Biopotential of immobilized amylases: a review. Indian J.Microbial., 40:1-14.

[9]. Beg. Q.K. and R. Gupta, 2003. Purification and characterization of an oxidation. Stable, thiol-dependent serine alkaline protease from Bacillus mojavensis. Enzyme. Microb. Technol., 32: 294-304.

[10]. Chang, 2002. Optimization of the production of and extracellular alkaline protease from Bacillus horikoshii. Process Biochem., 38, 155-159.

[11]. Chen, X. G., O. Stabnikova, J.H. Tay, J. Y. Wang and S.T. Lee Tay, 2004. Thermo active xtracellular protease of Geobacillus caldoproteolyticus.,nov., from sewage sludge. Extremophiles. 8: 489-498.

[12]. Cheong, J.Y., N.A.A. Aziz, R. Go, N.U.Azmi,N.S.A. Ghafar, A.A. Adli and M. Mustafa, 2014. The availability of astaxanthin from shrimp shell wastes through microbial fermentations, Aeromonas hydrophila and cell disruptions. Int. J.Agric.Bio., 16: 277-284.

[13]. Chu, I.M., C.Lee and T.S.Li, 1992. Production and degradation of alkaline protease in batch cultures of Bacillus subtilis. ATCC 14416. Enzym. Microb. Technol., 4.55-61.

[14]. Deng, A.,J. Wu, Y. Zhang, G. Zhang, and T. Wen, 2010. Purification and characterization of a surfactant stable high alkaline protease from Bacillus sp. B001. Bioresour. Technol., 101: 7100-7106.

[15]. Dutta, A., J. Wu, Y.Zhang, G. Zhang, and T. Wen, 2010. Isolation and characterization of newly isolated Pseudomonas mutant for protease production. Brazilian Arch. Biol. Technol., 49 (1): 37-47.

[16]. Esakkiraj, P., G. Immanuel, S.M. Sowmya, P. Iyapparaj and A. Palavesam, 2008. Evaluation of protease producing ability of fish gut isolate Bacillus cereus for aqua feed. Food Biopro. Technol., DOI 10. 1007/s 11947-007-0046-6.

[17]. Gessesse, A., R.H. Kaul, B.A. Gashe and B. Mattiasson, 2003. Novel alkaline protease from alkaliphilic bacteria grown on chicken feather. Enzyme Microb. Technol., 32: 519-524.

[18]. Heidari, H.R. K., M.A. Amoozegar, M. Hajighasemi, A.A. Ziaee and A. Ventosa, 2009. Production, optimization and purification of a novel extracellular protease from the moderately halophilic bacterium Halobacillus Karajensis, J. Ind. Microbial. Biotechnol., 35: 121-131.

[19]. Hossain, M.T., H.M. Cherry and M.N. Anwar, 2005. Optimization of some factors affecting the production of glucoamylase by Aspergillus funiculosus. Indian J. Microbiol., 45(2): 143-146. 
[20]. Joo, H.S., C. Ganesh Kumar, G.C. Park, K.T. Kim, S. R. Paik and C.S. Kumar, D. and T.C. Bhalla, 2004. Purification and characterization of small size protease from Bacillus sp., APR-4. Indian J. Exp. Biol. 42. 515-521.

[21]. Manivannan, S., D. Nagavally and T. Ramanathan, 2004. Alkaline protease production and assay parameters optimization in estuary isolate of Aspergillus sp. Indian J. Appl. Microbiol. 4(1): 31-35.

[22]. Meenu, M., S. Dhillon and R. Singh, 2000. Production of alkaline protease by a UV-mutant of Bacillus polymyxa. Indian J. Microbiol., 40: 25-28.

[23]. Nawani, N. N., D. Prakash and B.P. Kapadnis, 2010. Extraction, purification and characterization of an antioxidant from marine waste using protease chitinase cocktail. World J. Microbiol. Biotechnol., 26: 1509-1517.

[24]. Okonko, I.O., O.P. Olabode and O.S. Okeleji, 2006. The role of biotechnology in the socio-economic advancement and national development: An overview. African J. Biotechnol., 5(19): 2354-2366.

[25]. Pandey, A., C.R. Soccol and D.Mitchell, 2000. New developments in solid-state fermentation. I: Bioprocesses and applications. Process Biochem., 35: 1153-1169.

[26]. Sabir, J. S. M. and E.E. Bestawy, 2009. Enhancement of alkaline protease production in Bacillus circulans using plasmid transformation. World. J Microbiol. Biotechnol., 25 (11) : 2021-2027.

[27]. Sachindra, N. M., N. Bhaskar and N.S. Mahendrakar, 2005. Carotenoids in different body components of Indian shrimps. J. Sci. Food Agric., $85: 167-172$.

[28]. Saxena, S.., J. Bahadur and A. Varma, 1993. Cellulose and hemicellulose degradation bacteria from termite gut and mound soils of India. Int. J. Microbiol., 33(1): 55-60.

[29]. Venugopal, M. and A. V. Saramma, 2006. Characteriazation of alkaline protease from Vibrio fluvialis strain VM10 isolated from a mangrove sediment sample and its application as laundry detergent additive. Process Biochem., 41: 1239-1243.

[30]. Wang. S. L., C.H. Yang, T. W. Liang and Y.H. Yen, 2008. Optimization of conditions for protease production by Chryseobacterium taeanense TKU001. Bioresour. Technol., 99:3700-3707.

[31]. Wang, S. L., Chia-Hsing, Chao, T.W.Liang and C.C. Chen, 2009. Purification and characterization of protease and chitinase from Bacillus cereus TKU006 and conversion of marine wastes by these enzymes. Mar. Biotechnol., 11: 334-344. 